\title{
Carbohydrate-Modified Magnetic Nanoparticles for Radical Scavenging
}

\author{
M. MOSKVIN ${ }^{1}$, D. HORÁK ${ }^{1}$ \\ ${ }^{1}$ Institute of Macromolecular Chemistry of the Czech Academy of Sciences, Prague, Czech \\ Republic
}

Received July 14, 2016

Accepted July 14, 2016

\section{Summary}

Maghemite $\left(\gamma-\mathrm{Fe}_{2} \mathrm{O}_{3}\right)$ nanoparticles, $12 \mathrm{~nm}$ in size, were prepared by co-precipitation of Fe(II) and Fe(III) chlorides with ammonium hydroxide and oxidation with hydrogen peroxide. To achieve stability and biocompatibility, obtained particles were coated with silica, to which glucose and ascorbic acid were bound by different mechanisms. The composite particles were thoroughly characterized by transmission electron microscopy, dynamic light scattering, elemental analysis, and FT-Raman and fluorescence spectroscopy to determine composition, morphology, size and its

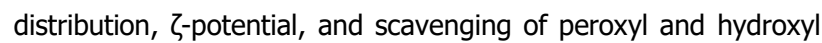
radicals. As the particles showed promising antioxidative properties, they may have a possible application as a stable magnetically controlled scavenger of reactive oxygen species.

\section{Key words}

Magnetic nanoparticles • Silica • Glucose • Ascorbic acid • Radical - Scavenging

\section{Corresponding author}

D. Horák, Institute of Macromolecular Chemistry of the Czech Academy of Sciences, Heyrovského nám. 2, 16206 Prague 6, Czech Republic. E-mail: horak@imc.cas.cz

\section{Introduction}

Naturally occurring carbohydrates and glycoconjugates (glycoproteins and glycolipids) play a crucial role in many diagnostic processes, such as recognition of antigens, cells, and their fragments (Olden et al. 1982). Carbohydrates are biocompatible, hydrophilic (mostly water-soluble), and can trigger various biological events including cell growth, inflammatory responses, or viral infections. These useful properties can be conveniently transferred on the glycosylated core-shell conjugates based on superparamagnetic nanoparticles. Such cores offer superior magnetic targetability and manipulability, and/or traceability in magnetic resonance imaging (MRI) due to the fact that iron oxides provide the targeted molecule with a large magnetic moment that creates substantial disturbances in the local magnetic field, leading to a rapid dephasing of water protons (Bulte and Kraitchman 2004). Besides applicability in drug delivery and sensing systems, magnetic nanoparticles are used also in treatment of cancer by hyperthermia (Wust et al. 2006). For cell labeling, crucial requirements consist in preparation of water-dispersible monocrystalline iron oxide nanoparticles, which are not only superparamagnetic, but also biocompatible, surfacefunctionalizable, and at the same time internalized by the cells. MR diagnostics of liver and spleen is their main application field as the particles with size $<50 \mathrm{~nm}$ are readily and almost completely internalized by the macrophages of these organs (Ferrucci and Stark 1990).

One of the key factors in the design of the magnetic nanoparticles for nanomedical applications is control of the size distribution, because the polydisperse particles differ in physical, chemical, and biological properties, in contrast to the monodisperse ones, the properties of which are uniform. A drawback of majority of iron oxide nanoparticles is that they consist of magnetite $\left(\mathrm{Fe}_{3} \mathrm{O}_{4}\right)$, which loses its properties in the presence of air oxygen. Due to the uncontrolled oxidation, magnetic properties are deteriorating; the colloid loses its stability and forms aggregates, which is unacceptable from the biomedical point of view. Therefore, controlled oxidation of $\mathrm{Fe}_{3} \mathrm{O}_{4}$ with hydrogen peroxide or sodium hypochlorite immediately after the synthesis is preferred resulting in maghemite $\left(\gamma-\mathrm{Fe}_{2} \mathrm{O}_{3}\right)$ 
(Babič et al. 2008), that is more stable in air and does not change its properties as quickly as the magnetite does (Sun et al. 2004). Moreover, $\mathrm{Fe}^{3+}$ ions of maghemite can be utilized for chelating bioactive compounds (Kraemer 2004). In contrast, $\mathrm{Fe}^{2+}$ ions of magnetite are known to catalyze decomposition of hydrogen peroxide in the cells forming $\mathrm{HO}^{\circ}$ radicals (Fenton reaction (Winterbourn 1995)) and can be toxic in high concentrations.

Biological applications require functionalized particles with inaccessible surface $\mathrm{Fe}$ ions. Magnetite/dextran conjugates (GastroMARK ${ }^{\circledR}$, Endorem ${ }^{\circledR}$ ) were the first commercially developed contrast agents approved for oral or intravenous introduction for magnetic resonance imaging (MRI) of bowels or liver (Wang 2011). Dextran, however, decomposes in acidic and alkaline media and cellular uptake of dextran-coated particles does not allow precise MR imaging due to the relatively poor endocytosis (Wilhelm et al. 2003).

Another class of surface-modified iron oxides is represented by $\gamma-\mathrm{Fe}_{2} \mathrm{O}_{3} \& \mathrm{SiO}_{2}$ core-shell ( $\mathrm{Lu}$ et. al. 2002) and/or carbohydrate-coated particles (Dorniani et al. 2012). While immobilization chemistry of polysaccharides is relatively simple, direct binding of mono-, di-, and oligosaccharides to iron oxide particles is rather difficult employing, e.g. reaction of aldehyde groups of reduced mono- and disaccharides with hydrazide groups of the particles (Lemieux and Bertozzi 1998). Another well-known approach consists in reductive amination of saccharides with amino groupcontaining supports (Gildersleeve et al. 2008, Geetha et al. 1995). Also carbohydrate-derived and especially polyprotic acids (glucuronic (Roque et al. 2009), ascorbic (Plug et al. 1984), D-gluconic (Kekkonen et al. 2009), hyaluronic (Kamat et al. 2010) and tannic (Iffat et al. 2005)) can be efficiently bound to the iron oxide surface by chemisorption. Due to formation of strong complexes, the acids are then firmly attached to the surface by ionic bonds. Last but not least, certain carbohydrate derivatives possessing antioxidative properties are useful as effective scavengers of reactive oxygen species (ROS). Aim of this report is to demonstrate possible enhancement of colloidal stability and scavenging activity of $\gamma-\mathrm{Fe}_{2} \mathrm{O}_{3}$ particles after their surface functionalization with glucose and ascorbic acid.

\section{Materials and Methods}

$\mathrm{FeCl}_{2} \cdot 4 \mathrm{H}_{2} \mathrm{O}, \mathrm{FeCl}_{3} \cdot 6 \mathrm{H}_{2} \mathrm{O}$, ascorbic acid (ASA), (3-isocyanatopropyl)triethoxysilane (ITS), 2,2'-azobis(2- amidinopropane) dihydrochloride (AAPH), 3,5-di-tertbutyl-4-hydroxytoluene (BHT), tetramethoxyorthosilicate (TMOS), diacetonide of D-glucose (DAG), and dexpanthenol (DXP) were obtained from Sigma-Aldrich (St. Louis, USA). Ethanol, N,N-dimethylformamide (DMF), propan-2-ol, 1,4-dioxane, cyclohexanol, iodine, and $\mathrm{Na}_{2} \mathrm{WO}_{4} \cdot 2 \mathrm{H}_{2} \mathrm{O}$ were from Lachema (Brno, Czech Republic). Hydrochloric acid (35\%), ammonium hydroxide $(25 \%)$, hydrogen peroxide (30\%), sodium bicarbonate and fluorescein were obtained from Lach-Ner (Neratovice, Czech Republic). Ultrapure Q-water from a Milli-Q Gradient A10 system (Millipore, Molsheim, France) was used throughout the experiments. All other reagent grade chemicals were purchased from SigmaAldrich and used as received.

\section{Preparation of $\gamma-\mathrm{Fe}_{2} \mathrm{O}_{3}$ colloid}

$\gamma-\mathrm{Fe}_{2} \mathrm{O}_{3}$ nanoparticles were prepared according to the previously developed technique (Patsula et al. 2016). Briefly, $0.3 \mathrm{M} \mathrm{FeCl}_{3}$ (40 mmol) and $1 \mathrm{M} \mathrm{FeCl}_{2}$ aqueous solutions $\left(20 \mathrm{mmol} ; \mathrm{Fe}^{3+} / \mathrm{Fe}^{2+}=2 \mathrm{~mol} / \mathrm{mol}\right)$ were charged in a 500-ml glass reactor equipped with a turbine impeller and the mixture was heated to $70^{\circ} \mathrm{C}$ with stirring (600 rpm). $25 \mathrm{wt} . \% \mathrm{NH}_{4} \mathrm{OH}(35 \mathrm{ml})$ was added to the mixture $\left(\mathrm{Fe}^{3+} \& \mathrm{Fe}^{2+} / \mathrm{NH}_{4} \mathrm{OH}=5 \mathrm{v} / \mathrm{v}\right)$, magnetite was precipitated and the reaction mixture heated to $90{ }^{\circ} \mathrm{C}$ for $1 \mathrm{~h}$ with stirring $(600 \mathrm{rpm})$. After cooling to room temperature, $35 \% \mathrm{HCl}$ was added to adjust $\mathrm{pH}$ to 5-6. Resulting $\mathrm{Fe}_{3} \mathrm{O}_{4}$ was oxidized to $\gamma-\mathrm{Fe}_{2} \mathrm{O}_{3}$ by adding $30 \%$ $\mathrm{H}_{2} \mathrm{O}_{2}\left(5 \mathrm{ml} ; \mathrm{Fe}^{3+} \& \mathrm{Fe}^{2+} / \mathrm{H}_{2} \mathrm{O}_{2}=1.2 \mathrm{~mol} / \mathrm{mol}\right)$ under slow heating from 20 to $90{ }^{\circ} \mathrm{C}$; reaction continued for $1 \mathrm{~h}$ with stirring $(550 \mathrm{rpm})$. Finally, the $\gamma-\mathrm{Fe}_{2} \mathrm{O}_{3}$ particles were washed three times with water $(100 \mathrm{ml}$ each) and magnetically separated. Particles were dispersed in water $(100 \mathrm{ml})$ under sonication (W-385 Heat SystemsUltrasonics; Farmingdale, NY, USA) at $50 \%$ output and $50 \%$ duty cycle for $10 \mathrm{~min}$. Concentration of the particles was $45 \mathrm{mg} / \mathrm{ml}$.

Preparation of 5-(2,2-dimethyl-1,3-dioxolan-4-yl)-2,2dimethyltetrahydrofuro[2,3-d][1,3]dioxol-6-yl (3-(triethoxysilyl)propyl)carbamate (DFSC)

ITS and DAG (2 mmol of each) were dissolved in dry 1,4 -dioxane $(20 \mathrm{ml})$ at $70^{\circ} \mathrm{C}$ for $6 \mathrm{~h}$ with magnetic stirring (600 rpm). 1,4-dioxane was vacuum-distilled off and the resulting DFSC was washed twice with cyclohexanol and vacuum-dried at $40{ }^{\circ} \mathrm{C}$. Structure of DFSC was confirmed by ${ }^{1} \mathrm{H}$ NMR (Fig. 1) using a Bruker Avance $300 \mathrm{MHz}$ spectrometer (Billerica, MA, USA). 


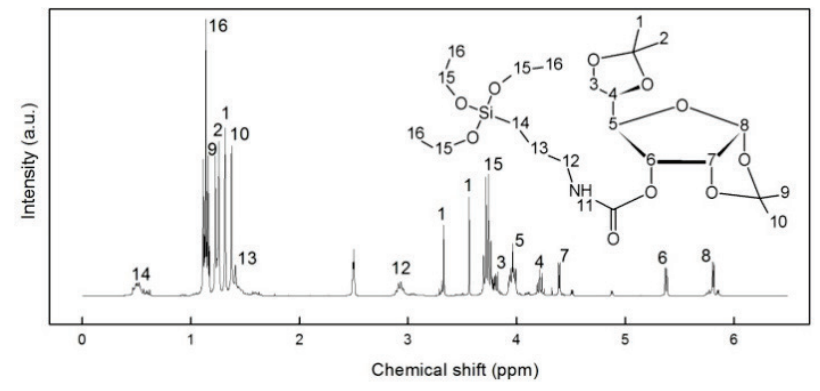

Fig. 1. ${ }^{1} \mathrm{H}$ NMR spectrum of DFSC.

\section{Modification of $\gamma-\mathrm{Fe}_{2} \mathrm{O}_{3}$ nanoparticle surface}

$\gamma-\mathrm{Fe}_{2} \mathrm{O}_{3}$ was modified in three steps with (i) $\mathrm{SiO}_{2}$, (ii) DFSC, and (iii) ASA.

(i) Typically, in a $25-\mathrm{ml}$ glass reactor equipped with a turbine impeller, TMOS $(20 \mathrm{mg})$ in propan-2$\mathrm{ol} /$ water $(8 / 1 \mathrm{v} / \mathrm{v})$ solution was added to aqueous $\gamma-\mathrm{Fe}_{2} \mathrm{O}_{3}$ colloid (100 mg of dry substance) to reach $25 \mathrm{ml}$ volume and $\mathrm{pH}$ was adjusted to 9 by addition of $25 \% \mathrm{NH}_{4} \mathrm{OH}$. The mixture was heated to $60^{\circ} \mathrm{C}$ for $8 \mathrm{~h}$ with stirring (500 rpm). Resulting $\gamma-\mathrm{Fe}_{2} \mathrm{O}_{3} \& \mathrm{SiO}_{2}$ nanoparticles Run $\mathrm{I} / 1$ (Table 1) were washed with water three times $(70 \mathrm{ml}$ each), magnetically separated and again dispersed in water $(20 \mathrm{ml})$ under sonication at $50 \%$ output for $3 \mathrm{~min}$.

(ii) $\gamma-\mathrm{Fe}_{2} \mathrm{O}_{3} \& \mathrm{SiO}_{2}$ particles Run I/1 (100 mg) were coated with $\mathrm{D}$-glucose by adding different amounts of DFSC (10, 20, 50, 100, and $200 \mathrm{mg}$ ) as described above. Hydroxyl groups of the resulting $\gamma-\mathrm{Fe}_{2} \mathrm{O}_{3} \& \mathrm{SiO}_{2}-$ DAG particles were deprotected by addition of $0.1 \mathrm{wt} . \%$ iodine in methanol under reflux $\left(50^{\circ} \mathrm{C}\right)$ for $8 \mathrm{~h}$ with stirring (500 rpm). Resulting glucose-containing $\gamma-\mathrm{Fe}_{2} \mathrm{O}_{3} \& \mathrm{SiO}_{2}-\mathrm{G}$ particles Run I/2-6 (Fig. 4) were washed with methanol and water (twice each) and transferred in water with sonication.

(iii) Finally, ASA was adsorbed on the $\gamma-\mathrm{Fe}_{2} \mathrm{O}_{3} \& \mathrm{SiO}_{2}-\mathrm{G}$ particles Run $\mathrm{I} / 3$ from aqueous solutions at different $\mathrm{ASA} / \gamma-\mathrm{Fe}_{2} \mathrm{O}_{3} \& \mathrm{SiO}_{2}-\mathrm{G}$ ratios $(0.1-2 \mathrm{w} / \mathrm{w})$ under purging with argon. Resulting $\gamma$ - $\mathrm{Fe}_{2} \mathrm{O}_{3} \& \mathrm{SiO}_{2}$-G-ASA nanoparticles Run II/1-5 were washed with water with sonication; concentration was adjusted to $4.4 \mathrm{mg} \gamma-\mathrm{Fe}_{2} \mathrm{O}_{3} \& \mathrm{SiO}_{2}$-G-ASA/ml.

\section{Determination of free-radical scavenging}

To measure scavenging ability of peroxyl radicals (ROO'), the $\gamma$ - $\mathrm{Fe}_{2} \mathrm{O}_{3} \& \mathrm{SiO}_{2}$-G-ASA particles (2, 4,8 , and $16 \mathrm{mg}$ ) were added to $2.4 \cdot 10^{-5} \mathrm{M}$ fluorescein solution in $0.02 \mathrm{M}$ sodium bicarbonate buffer (SBB; $2 \mathrm{ml} ; \mathrm{pH}=7.4)$ and DMF $(1 \mathrm{ml})$. After addition of freshly prepared AAPH $(30 \mathrm{mg})$ solution in $0.16 \mathrm{M} \mathrm{SBB}(3 \mathrm{ml})$, the radicals were formed and fluorescence spectrum measured for $1 \mathrm{~h}$ using a JASCO FP-6200 spectrofluorometer (Tokyo, Japan); each experiment was performed in triplicate and BHT was used as a positive control. Relative scavenging activity $A^{\prime}(\%)$ of the particles was evaluated according to the following formula (1):

$$
A^{\prime}=100 \cdot\left(I \cdot K-I_{0}\right) /\left(1-I_{0}\right)
$$

where $I_{0}$ and $I$ are relative fluorescence intensities of the blank (without the particles) and particle dispersion, respectively, measured $30 \mathrm{~min}$ after beginning of the experiment and $K$ is factor taking in account light scattering by the particles. Absolute scavenging activity $A(\mathrm{mmol} / \mathrm{g})$ was calculated according to equation (2):

$$
A=\left[2 \cdot \mathrm{A}^{\prime} \cdot \omega\right] /[10 \cdot \mathrm{M}]=1.136 \cdot 10^{-3} \cdot A^{\prime} \cdot \omega
$$

where $\omega$ is content of ASA in the particles (wt.\%) and $\mathrm{M}$ is molar mass of ASA $(176.1 \mathrm{~g} / \mathrm{mol})$.

To evaluate scavenging activity of the hydroxyl radicals $\left(\mathrm{HO}^{\circ}\right)$, the particles $(1,2,4,6$, and $12 \mathrm{mg}$ ) were added to $2.4 \cdot 10^{-5} \mathrm{M}$ fluorescein solution $(10 \mu \mathrm{l})$. Subsequently, $7.3 \mathrm{mM} \mathrm{Na}_{2} \mathrm{WO}_{4}$ solution in SBB $(20 \mu \mathrm{l})$ and $30 \% \mathrm{H}_{2} \mathrm{O}_{2}(100 \mu \mathrm{l})$ were added. Fluorescence of the colloid was monitored for $1.5 \mathrm{~h}$; each experiment was performed in duplicate and DXP was used as a positive control. The particle scavenging activity was evaluated $1 \mathrm{~h}$ after beginning of the experiment.

\section{Characterization of particles}

Maghemite nanoparticles were observed by a Tecnai Spirit $G^{2}$ transmission electron microscope (TEM; FEI; Brno, Czech Republic). Number-average diameter $\left(D_{\mathrm{n}}=\Sigma D_{\mathrm{i}} / \mathrm{N}, D_{\mathrm{i}}\right.$ is diameter of $\mathrm{i}$-th particle and $\mathrm{N}$ is total number of the particles), weight-average diameter $\left(D_{\mathrm{w}}=\Sigma D_{\mathrm{i}}^{4} / \Sigma D_{\mathrm{i}}^{3}\right)$ and polydispersity index $\left(\mathrm{PDI}=D_{\mathrm{w}} / D_{\mathrm{n}}\right)$ were calculated from at least 300 individual particles on the micrographs using Atlas software (Tescan Digital Microscopy Imaging; Brno, Czech Republic). Surface zeta $(\zeta)$ potential and hydrodynamic diameter $D_{\mathrm{h}}$ were measured by dynamic light scattering (DLS) using a ZEN3600 Nano-ZS Zetasizer (Malvern Instruments; Malvern, Worcestershire, UK). FT-Raman spectra were measured on a Thermo Nicolet 6700 FT-IR spectrometer with attached NIR FT-Raman module (Thermo Fisher Scientific; Waltham, USA). Excitation laser with the $180^{\circ}$ reflecting sample geometry and $1,064 \mathrm{~nm}$ wave- 
length was used in pair with air-cooled In-Ga-As detector. Carbon and nitrogen content was determined on a Perkin-Elmer $2400 \mathrm{CHN}$ elemental analyzer (Waltham, MA, USA).

\section{Results}

\section{Synthesis of $\gamma-\mathrm{Fe}_{2} \mathrm{O}_{3}$ nanoparticles}

$\gamma-\mathrm{Fe}_{2} \mathrm{O}_{3}$ nanoparticles were obtained by coprecipitation of $\mathrm{FeCl}_{2}$ and $\mathrm{FeCl}_{3}$ with ammonia and oxidation with hydrogen peroxide (Fig. 4). Figure 2a shows TEM micrograph of $\gamma-\mathrm{Fe}_{2} \mathrm{O}_{3}$ nanoparticles, that are almost spherical in shape with a mean diameter of $12 \mathrm{~nm}$ and moderately broad particle size distribution (PDI=1.3). Because the particles have to be dried before TEM imaging, they tend to form aggregates, however, the individual particles are still distinguishable on the micrographs and the particle size can be analyzed. As expected, the hydrodynamic particle size was substantially larger $\left(D_{\mathrm{h}}=64 \mathrm{~nm}\right)$ due to particle cluster formation in water; moreover, z-average diameter in DLS measurements is always $>D_{\mathrm{n}}$. FT-Raman spectrum of the $\gamma-\mathrm{Fe}_{2} \mathrm{O}_{3}$ particles showed vibration bands at 560 and $1,090 \mathrm{~cm}^{-1}$ attributed to the maghemite crystal lattice and surface hydroxyl groups, respectively (Fig. 3a).
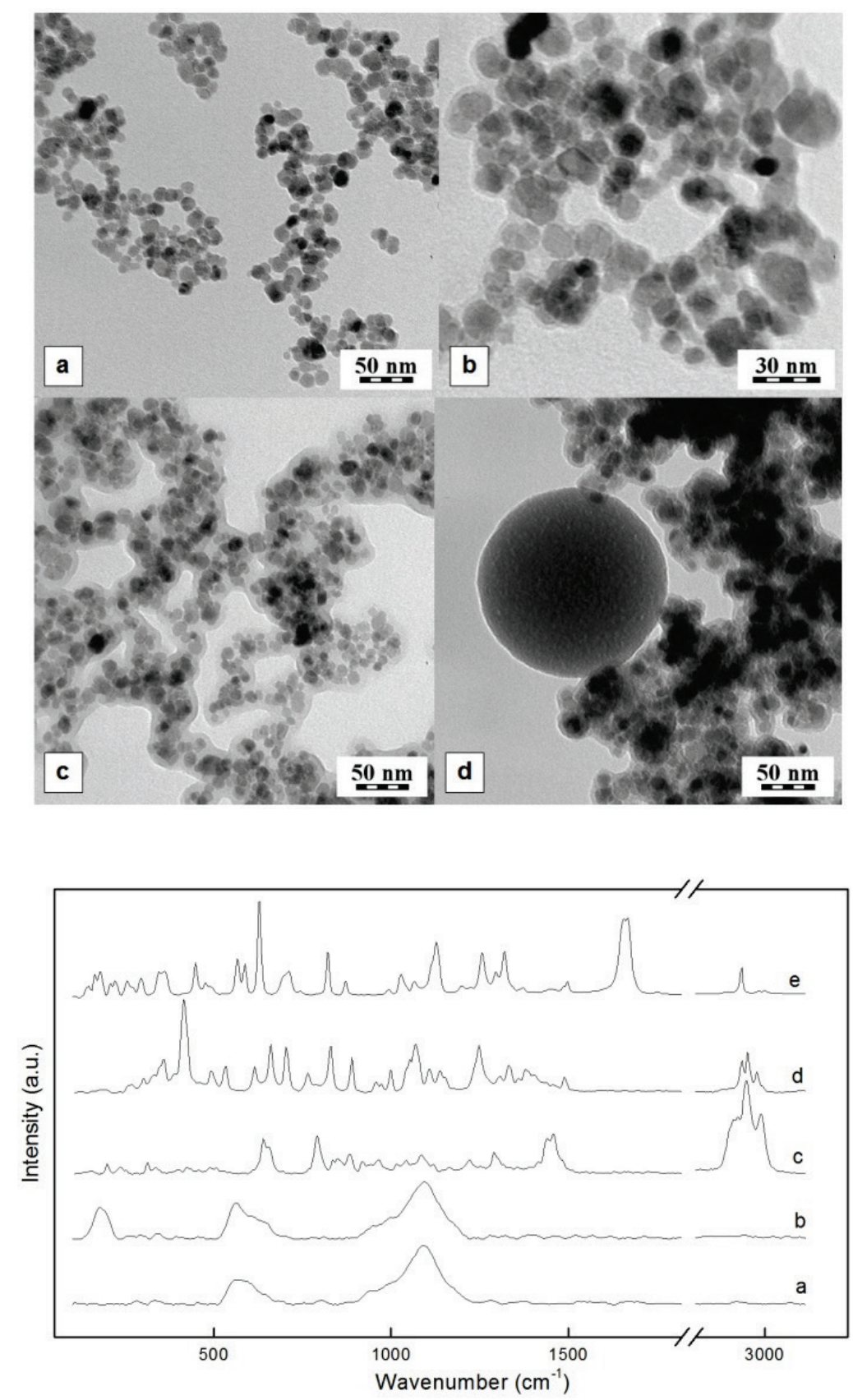

Fig. 2. TEM micrographs of a) $\gamma-\mathrm{Fe}_{2} \mathrm{O}_{3}$, b) $\gamma-\mathrm{Fe}_{2} \mathrm{O}_{3} \& \mathrm{SiO}_{2}$ Run $\mathrm{I} / 3$, c) $\mathrm{I} / 4$, and d) I/6.

Fig. 3. FT-Raman spectra of a) $\gamma-\mathrm{Fe}_{2} \mathrm{O}_{3}$, b) $\gamma-\mathrm{Fe}_{2} \mathrm{O}_{3} \& \mathrm{SiO}_{2}$, c) $\gamma-\mathrm{Fe}_{2} \mathrm{O}_{3} \& \mathrm{SiO}_{2}-\mathrm{DAG}$, d) $\gamma-\mathrm{Fe}_{2} \mathrm{O}_{3} \& \mathrm{SiO}_{2}-\mathrm{G}$, and e) $\gamma-\mathrm{Fe}_{2} \mathrm{O}_{3} \& \mathrm{SiO}_{2}-\mathrm{G}-$ ASA nanopar-ticles. 


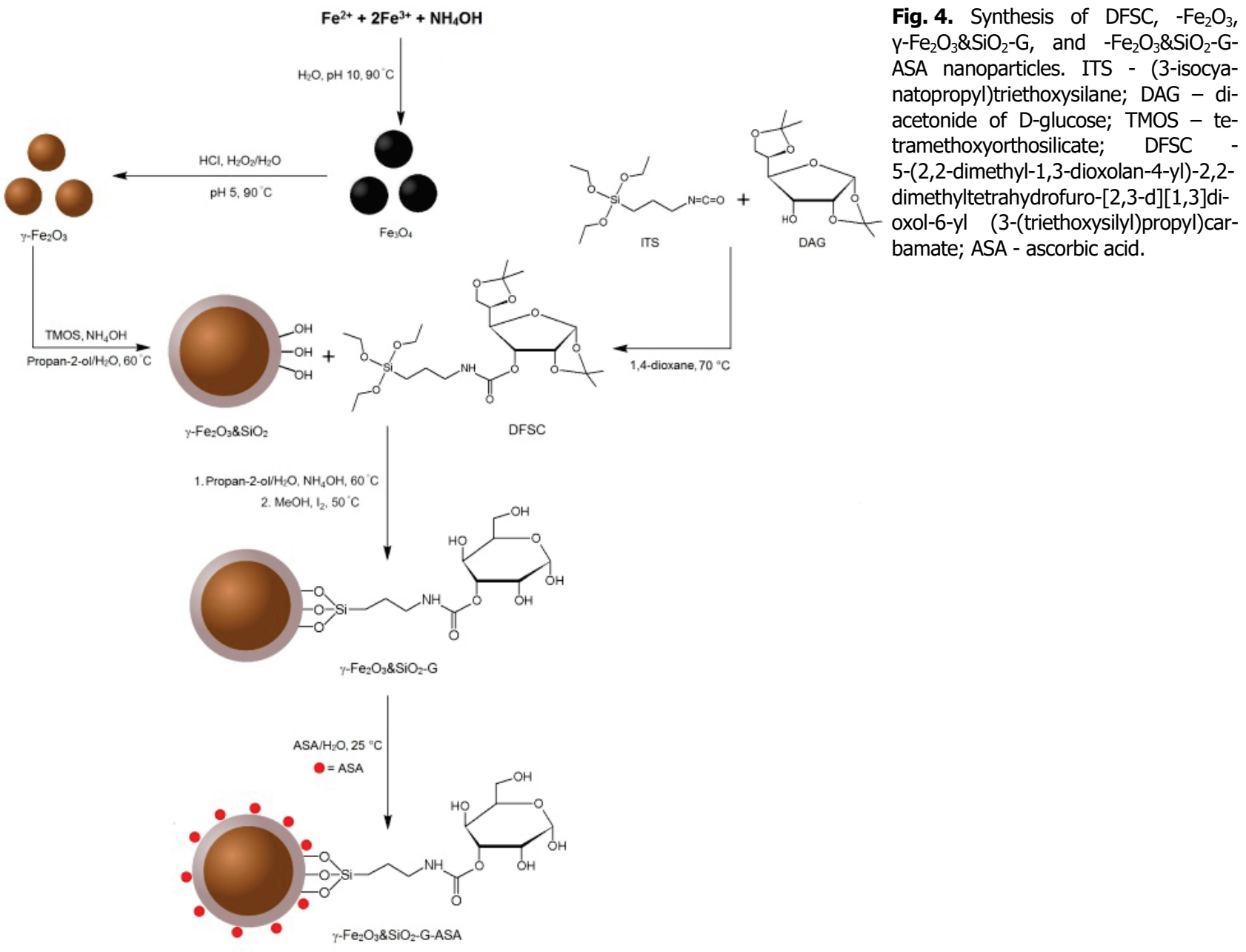

Surface modification of $\gamma-\mathrm{Fe}_{2} \mathrm{O}_{3}$ with $\mathrm{SiO}_{2}, \mathrm{DFSC}$, and $A S A$

(i) Surface of starting $\gamma-\mathrm{Fe}_{2} \mathrm{O}_{3}$ was modified with silica using TMOS as a precursor, which undergoes hydrolysis and condensation in alkaline medium $\left(\mathrm{NH}_{4} \mathrm{OH}\right)$. Rather low TMOS $/ \gamma-\mathrm{Fe}_{2} \mathrm{O}_{3}$ ratio $(0.1 \mathrm{w} / \mathrm{w})$ was applied to produce a thin $\mathrm{SiO}_{2}$ shell $(\sim 1 \mathrm{~nm})$. Presence of silica coating on the $\gamma-\mathrm{Fe}_{2} \mathrm{O}_{3} \& \mathrm{SiO}_{2}$ particles Run I/1 (Table 1) was confirmed by TEM, as well as by FT Raman spectrum (Fig. 3b), where a new vibration peak typical for silicates was observed at $180 \mathrm{~cm}^{-1}$.

(ii) Surface of the nanoparticles Run I/1 was modified with DFSC obtained from ITS and DAG (Fig. 4). DFSC contains D-glucose (G), which increases stability of obtained composite particles in aqueous media. For preparation of $\gamma-\mathrm{Fe}_{2} \mathrm{O}_{3} \& \mathrm{SiO}_{2}-\mathrm{G}$ particles, $\mathrm{DFSC} / \gamma-\mathrm{Fe}_{2} \mathrm{O}_{3} \& \mathrm{SiO}_{2}$ ratio was varied from 0.2 to $2 \mathrm{w} / \mathrm{w}$ (Table 1). The $\gamma-\mathrm{Fe}_{2} \mathrm{O}_{3} \& \mathrm{SiO}_{2}-\mathrm{G}$ particles Runs $\mathrm{I} / 2-6$ were $14-38 \mathrm{~nm}$ in size with PDI 1.3-1.6. With increasing $\mathrm{DFSC} / \gamma-\mathrm{Fe}_{2} \mathrm{O}_{3} \& \mathrm{SiO}_{2}$ ratio, amount of D-glucose bound to the particles and thickness of $\gamma-\mathrm{Fe}_{2} \mathrm{O}_{3} \& \mathrm{SiO}_{2}-\mathrm{G}$ shell substantially increased from 1.7 to $11 \mathrm{wt} . \%$ and from 1 to
$13 \mathrm{~nm}$, respectively, as well as $D_{\mathrm{h}}$ increased up to $\sim 250 \mathrm{~nm}$ (Table 1). DLS was used also to determine the particle size distribution. Polydispersity $\mathrm{PI} 0.25$ of $\gamma-\mathrm{Fe}_{2} \mathrm{O}_{3} \& \mathrm{SiO}_{2}-\mathrm{G}$ nanoparticles Run $\mathrm{I} / 3$ obtained at optimal DFSC $/ \gamma-\mathrm{Fe}_{2} \mathrm{O}_{3} \& \mathrm{SiO}_{2}$ ratio was in agreement with PDI values according to TEM characterizing moderately broad distribution. At high $\mathrm{DFSC} / \gamma-\mathrm{Fe}_{2} \mathrm{O}_{3} \& \mathrm{SiO}_{2}$ ratio (Run I/6), however, neat silica-DAG spheres were formed $(\sim 100 \mathrm{~nm}$ in size) and particles tended to aggregate (Fig. 2d).

Successful modification was confirmed by FT-Raman spectroscopy, where presence of DFSC on the particles was documented by peaks at 200 and $1,085 \mathrm{~cm}^{-1}$ corresponding to stretching deformations $v(\mathrm{Si}-\mathrm{O}-\mathrm{Si})$ and $\delta(\mathrm{Si}-\mathrm{C})$, respectively, as well as peaks at 640 and $790 \mathrm{~cm}^{-1}$ representing ring vibrations of DAG (Fig. 3c). Bands at 1,290 and $1,450 \mathrm{~cm}^{-1}$ were ascribed to the $v(\mathrm{C}-\mathrm{O}-\mathrm{C})$ and $v(\mathrm{NH}-\mathrm{CO})$ bond vibrations, respectively. Finally, strong signals at 2,930 and $2,990 \mathrm{~cm}^{-1}$ were attributed to the $v_{\text {as }}\left(\mathrm{C}-\mathrm{CH}_{3}\right)$ vibrations of the double substituted semiacetal DAG cycles.

After the DAG cleavage, formation of glucose 
Table 1. Characterization of $\gamma-\mathrm{Fe}_{2} \mathrm{O}_{3} \& \mathrm{SiO}_{2}-\mathrm{G}$ nanoparticles.

\begin{tabular}{cccccccc}
\hline Run & $\begin{array}{c}\mathbf{D F S C} / \boldsymbol{\gamma}-\mathrm{Fe}_{\mathbf{2}} \mathbf{O}_{\mathbf{3}} \& \mathbf{S i O}_{2} \\
(\mathbf{w} / \mathbf{w})\end{array}$ & $\begin{array}{c}\boldsymbol{D}_{\mathbf{n}} \\
(\mathbf{n m})\end{array}$ & $\mathbf{P D I}$ & $\begin{array}{c}\boldsymbol{D}_{\mathbf{h}} \\
(\mathbf{n m})\end{array}$ & $\mathbf{P I}$ & $\begin{array}{c}\zeta \text {-potential } \\
(\mathbf{m V})\end{array}$ & $\begin{array}{c}\text { Bound } \\
\text { glucose } \\
(\mathbf{w t .} \%)\end{array}$ \\
\hline$I / 1$ & 0 & 13 & 1.28 & 126 & 0.24 & 42 & 0 \\
$I / 2$ & 0.1 & 14 & 1.34 & 94 & 0.23 & 36 & 1.7 \\
$I / 3$ & 0.2 & 16 & 1.32 & 82 & 0.25 & 35 & 3.0 \\
$I / 4$ & 0.5 & 20 & 1.42 & 109 & 0.30 & 36 & 4.6 \\
$I / 5$ & 1 & 26 & 1.48 & 168 & 0.37 & 35 & 7.7 \\
$I / 6$ & 2 & 38 & 1.62 & 253 & 0.46 & 33 & 11 \\
\hline
\end{tabular}

DFSC - 5-(2,2-dimethyl-1,3-dioxolan-4-yl)-2,2-dimethyltetrahydrofuro[2,3-d][1,3]dioxol-6-yl (3-(triethoxysilyl)propyl)carbamate; $D_{\mathrm{n}}$ - number-average diameter (TEM); PDI - polydispersity index (TEM); $D_{\mathrm{h}}$ - hydrodynamic diameter (DLS); PI - polydispersity (DLS).

Table 2. Characterization of $\gamma-\mathrm{Fe}_{2} \mathrm{O}_{3} \& \mathrm{SiO}_{2}-\mathrm{G}-\mathrm{ASA}$ nanoparticles originating from $\gamma-\mathrm{Fe}_{2} \mathrm{O}_{3} \& \mathrm{SiO}_{2}-\mathrm{G}$ Run I/3.

\begin{tabular}{cccccccccc}
\hline Run & $\begin{array}{c}\mathbf{A S A} / \boldsymbol{\gamma}-\mathbf{F e}_{\mathbf{2}} \mathbf{O}_{3} \& \mathbf{S i O}_{2}-\mathbf{G} \\
\mathbf{( w / w )}\end{array}$ & $\begin{array}{c}\boldsymbol{D}_{\mathbf{n}} \\
(\mathbf{n m})\end{array}$ & $\mathbf{P D I}$ & $\begin{array}{c}\boldsymbol{D}_{\mathbf{h}} \\
(\mathbf{n m})\end{array}$ & $\mathbf{P I}$ & $\begin{array}{c}\zeta \text {-potential } \\
(\mathbf{m V})\end{array}$ & $\begin{array}{c}\text { Bound ASA } \\
(\mathbf{w t .} \%)\end{array}$ & $\begin{array}{c}\boldsymbol{A}_{\text {ROo. }} \\
(\mathbf{m m o l} / \mathbf{g})\end{array}$ & $\begin{array}{c}\boldsymbol{A}_{\mathbf{H O} \cdot} \\
(\mathbf{m m o l} / \mathbf{g})\end{array}$ \\
\hline$I I / 1$ & 0.1 & 18 & 1.34 & 68 & 0.23 & -33 & 5.8 & 0.024 & 0.042 \\
$I I / 2$ & 0.2 & 18 & 1.32 & 74 & 0.27 & -37 & 9.1 & 0.084 & 0.103 \\
$I I / 3$ & 0.5 & 19 & 1.28 & 79 & 0.22 & -36 & 14.2 & 0.226 & 0.290 \\
$I I / 4$ & 1 & 19 & 1.33 & 83 & 0.24 & -42 & 21.1 & 0.887 & 1.05 \\
$I I / 5$ & 2 & 20 & 1.30 & 86 & 0.29 & -40 & 26.5 & 1.63 & 1.90 \\
$I I / 6$ & 20 & 1.32 & 88 & 0.27 & -46 & 28.9 & 2.31 & 2.70 \\
\hline
\end{tabular}

ASA - ascorbic acid; $D_{\mathrm{n}}$ - number-average diameter (TEM); PDI - polydispersity index (TEM); $D_{\mathrm{h}}$ - hydrodynamic diameter (DLS);

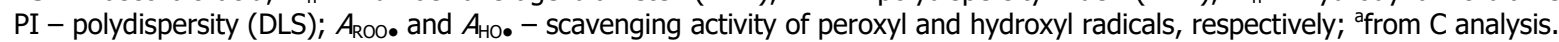

was confirmed by presence of peaks at 661 and $704 \mathrm{~cm}^{-1}$ attributed to $\delta(\mathrm{C}-\mathrm{O})$ wagging vibrations of $\mathrm{CH}-\mathrm{OH}$ groups (Fig. 3d). Bands at 1,068 and $1,137 \mathrm{~cm}^{-1}$ were ascribed to stretching $v(\mathrm{C}-\mathrm{O})$ of primary and secondary hydroxyl groups, respectively. Peak at $1,248 \mathrm{~cm}^{-1}$ documented presence of $v_{\text {as }}(\mathrm{C}-\mathrm{O}-\mathrm{C})$ stretching vibrations of ether oxygen bonds in glucose. Peak at $1,488 \mathrm{~cm}^{-1}$ was attributed to methylene group scissoring vibrations $\delta(\mathrm{H}-\mathrm{C}-\mathrm{H})$. Also a strong peak at $420 \mathrm{~cm}^{-1}$ showed the $\delta(\mathrm{C}-\mathrm{C})$ vibrations of the propyl chain.

(iii) $\gamma-\mathrm{Fe}_{2} \mathrm{O}_{3} \& \mathrm{SiO}_{2}-\mathrm{G}$ particles Run $\mathrm{I} / 3$ were used for investigation of ASA adsorption (Table 2). With increasing ASA $/ \gamma-\mathrm{Fe}_{2} \mathrm{O}_{3} \& \mathrm{SiO}_{2}-\mathrm{G}$ ratio, both $D_{\mathrm{n}}$ and $D_{\mathrm{h}}$ of $\gamma-\mathrm{Fe}_{2} \mathrm{O}_{3} \& \mathrm{SiO}_{2}$-G-ASA slightly increased from 18 to 20 and from 68 to $88 \mathrm{~nm}$, respectively, due to formation of a thin carbohydrate layer fixed to the $\mathrm{SiO}_{2}$ surface; thick multimolecular layer was not produced. The $\gamma-\mathrm{Fe}_{2} \mathrm{O}_{3} \& \mathrm{SiO}_{2}$-G-ASA particle size distribution did not change (PDI 1.3).

To confirm presence of $\mathrm{G}$ and ASA on the
$\gamma-\mathrm{Fe}_{2} \mathrm{O}_{3} \& \mathrm{SiO}_{2}-\mathrm{G}$ and $\gamma-\mathrm{Fe}_{2} \mathrm{O}_{3} \& \mathrm{SiO}_{2}$-G-ASA nanoparticle surface, the carbon content was analyzed. Percentage of adsorbed ASA was then calculated by comparing carbon amount found in DFSC, ASA, and modified particles (Table 1 and 2). With increasing $\mathrm{ASA} / \gamma-\mathrm{Fe}_{2} \mathrm{O}_{3} \& \mathrm{SiO}_{2}-\mathrm{G}$ ratio, amount of adsorbed ASA increased up to 29 wt.\% reaching a plateau, which is typical for Langmuir adsorption (Masel 1996). This adsorption limit corresponds to saturation equilibrium of adsorbate and is equal to the highest possible surface occupation.

FT-Raman spectrum of the $\gamma-\mathrm{Fe}_{2} \mathrm{O}_{3} \& \mathrm{SiO}_{2}$-GASA Run II/5 had typical peaks at 628 and $1,028 \mathrm{~cm}^{-1}$ corresponding to the out-of-plane $\mathrm{OH}$ deformation and ring bend vibrations of ASA, respectively (Fig. 3e). Peaks at $819,1,128,1,667$, and $2,919 \mathrm{~cm}^{-1}$ were ascribed to the stretching deformations of $\mathrm{C}-\mathrm{C}, \mathrm{C}-\mathrm{O}-\mathrm{C}$, and $\mathrm{C}=\mathrm{C}$ groups of the ASA carbon ring and $\mathrm{CH}$ stretching of the carbon chain, respectively. The FT-Raman spectra thus also demonstrated successful coating of the particle surface with $\mathrm{G}$ and ASA. 
Finally, $\quad \gamma-\mathrm{Fe}_{2} \mathrm{O}_{3} \& \mathrm{SiO}_{2}$-G-ASA free-radical scavenging activity in SBB buffer was spectrophotometrically determined (Poláková et al. 2015). SBB buffer was selected for these experiments as it prevents the particle agglomeration, in contrast to phosphate-buffered saline, where the particles aggregate due to high affinity of phosphate ions to iron oxides. Also Good's buffers were found unsuitable for ROS determination due to their reactivity with the radicals (Grady et al. 1988). During the investigation, ROO ${ }^{\circ}$ and $\mathrm{HO}^{\circ}$ radicals formed by decomposition of AAPH and $\mathrm{H}_{2} \mathrm{O}_{2}$, respectively, decreased fluorescence due to oxidation of fluorescein in the reaction mixture. With increasing ASA content in the $\gamma-\mathrm{Fe}_{2} \mathrm{O}_{3} \& \mathrm{SiO}_{2}$-G-ASA particles, saturation adsorption was reached and the scavenging activity dramatically increased, which can be explained by a high ASA diffusion from the particle surface in the liquid phase. Maximum scavenging activity was found in $\gamma$ - $\mathrm{Fe}_{2} \mathrm{O}_{3} \& \mathrm{SiO}_{2}$-G-ASA nanoparticles Run II/6 (containing almost 30 wt.\% ASA), which captured 2.3 and $2.7 \mathrm{mmol}^{\circ} \mathrm{ROO}^{\circ}$ and $\mathrm{HO}^{\circ}$ perg, respectively (Table 2), while pure ASA captured $\sim 11 \mathrm{mmol}$ of both radicals/g.

\section{Discussion}

$\mathrm{Fe}_{3} \mathrm{O}_{4}$ nanoparticles were obtained by coprecipitation of iron salts in basic medium (Fig. 4), which is a relatively easy and versatile method of iron oxide synthesis (Massart 1981). Several reaction parameters are crucial for formation of stable colloids with a relatively narrow particle size distribution, such as $\mathrm{Fe}^{2+} / \mathrm{Fe}^{3+}$ ratio $=2 \mathrm{~mol} / \mathrm{mol}$, type of the salt (chloride, nitrate, sulfate), amount of precipitating base, temperature, $\mathrm{pH}$, stirring speed, etc. In this report, Fe chlorides and ammonia were preferred reactants used at temperatures 70 and $90{ }^{\circ} \mathrm{C}$. To obtain $\gamma-\mathrm{Fe}_{2} \mathrm{O}_{3}$, which is more oxidatively stable than $\mathrm{Fe}_{3} \mathrm{O}_{4}$ due to the absence of $\mathrm{Fe}^{2+}$ ions, hydrogen peroxide was used as a strong oxidation agent, which does not produce undesirable byproducts. Oxidant/magnetite ratio, $\mathrm{pH}$, temperature, reaction time, as well as subsequent washing and sonication, play an important role in preparation of a high-quality product.

To enhance the radical scavenging ability and to avoid oxidative stress caused by traces of $\mathrm{Fe}^{2+}$ ions leaching from the $\gamma-\mathrm{Fe}_{2} \mathrm{O}_{3}$ particles, their surface was coated with silica, D-glucose, and finally modified with ASA; resulting nanoparticles were termed as $\gamma-\mathrm{Fe}_{2} \mathrm{O}_{3} \& \mathrm{SiO}_{2}-\mathrm{G}-\mathrm{ASA}$ (Fig. 4). It is interesting to note that $D_{\mathrm{h}}$ of initial $\gamma-\mathrm{Fe}_{2} \mathrm{O}_{3} \& \mathrm{SiO}_{2}$ particles $(126 \mathrm{~nm})$ decreased after reaction with DFSC at $\mathrm{DFSC} / \gamma-\mathrm{Fe}_{2} \mathrm{O}_{3} \& \mathrm{SiO}_{2}=0.1$ and $0.2 \mathrm{w} / \mathrm{w}$ to 94 and $82 \mathrm{~nm}$, respectively. This is ascribed to decreased particle clustering during DLS measurements due steric repulsion of D-glucose attached to the particles. D-glucose can be thus considered as an excellent hydrophilic modification agent inducing high colloidal stability of the particles. The $\gamma-\mathrm{Fe}_{2} \mathrm{O}_{3} \& \mathrm{SiO}_{2}-\mathrm{G}$ particles Run $\mathrm{I} / 3$ were then used in the final ASA adsorption experiments. With $\mathrm{DFSC} / \gamma$ $\mathrm{Fe}_{2} \mathrm{O}_{3} \& \mathrm{SiO}_{2}$ ratio $>0.2 \mathrm{w} / \mathrm{w}$, glucose-modified silica shell thickness increased and induced particle aggregation in water. As a result, $D_{\mathrm{h}}$ of $\gamma-\mathrm{Fe}_{2} \mathrm{O}_{3} \& \mathrm{SiO}_{2}-\mathrm{G}$ nanoparticles Run I/4-6 was substantially larger than in Run $\mathrm{I} / 2$ and $\mathrm{I} / 3$. As expected hydrodynamic particle diameter was always larger than the size from TEM, which measures particles in dry state, where carbohydrate moieties are in a collapsed state. While $\gamma-\mathrm{Fe}_{2} \mathrm{O}_{3} \& \mathrm{SiO}_{2}$ and $\gamma-\mathrm{Fe}_{2} \mathrm{O}_{3} \& \mathrm{SiO}_{2}-\mathrm{G}$ particles had a positive charge (ca. $35 \mathrm{mV}$ ), ASA (due to presence of acidic hydroxyl groups) introduced negative charges on the surface, absolute value of which increased from 33 to $46 \mathrm{mV}$ with increasing $\mathrm{ASA} / \gamma-\mathrm{Fe}_{2} \mathrm{O}_{3} \& \mathrm{SiO}_{2}-\mathrm{G}$ ratio. Since it is wellknown that absolute values of $\zeta$-potential $>30 \mathrm{mV}$ render the particles with colloid stability (Babič et al. 2009), there is no surprise that the $\gamma-\mathrm{Fe}_{2} \mathrm{O}_{3} \& \mathrm{SiO}_{2}-\mathrm{G}-\mathrm{ASA}$ particles Run II did not exhibit any tendency to aggregation. However, as expected, each modification step increased the particle size.

\section{Conclusions}

The $\quad \gamma-\mathrm{Fe}_{2} \mathrm{O}_{3} \& \mathrm{SiO}_{2}-\mathrm{G}-\mathrm{ASA}$ nanoparticles demonstrated remarkable free-radical scavenging activity, which reached $70 \%$ of that for pure ASA. Such nanoparticles, combining both magnetic targetability and antioxidative activity, can in future undoubtedly find new biomedical applications, in particular, for treatment of fatal disorders, such are cardiovascular and neurodegenerative diseases and cancer.

\section{Conflict of Interest}

There is no conflict of interest.

\section{Acknowledgements}

This work was supported by the Ministry of Education, Youth and Sports of CR within the National Sustainability Program II (Project BIOCEV-FAR LQ1604). 


\section{References}

BABIČ M, HORÁK D, JENDELOVÁ P, GLOGAROVÁ K, HERYNEK V, TRCHOVÁ M, LIKAVČANOVÁ K, HÁJEK M, SYKOVÁ E: Poly( $N, N$-dimethylacrylamide)-coated maghemite nanoparticles for stem cell labeling. Bioconjug Chem 20: 283-294, 2009.

BABIČ M, HORÁK D, TRCHOVÁ M, JENDELOVÁ P, GLOGAROVÁ K, LESNÝ P, HERYNEK V, HÁJEK M, SYKOVÁ E: Poly(L-lysine)-modified iron oxide nanoparticles for stem cell labeling. Bioconjugate Chem 19: 740-750, 2008.

BULTE JWM, KRAITCHMAN DL: Iron oxide MR contrast agents for molecular and cellular imaging. NMR Biomed 17: 484-499, 2004.

DORNIANI D, HUSSEIN MZB, KURA AU, FAKURAZI S, SHAARI AH, AHMAD Z: Preparation of $\mathrm{Fe}_{3} \mathrm{O}_{4}$ magnetic nanoparticles coated with gallic acid for drug delivery. Int J Nanomed 7: 5745-5756, 2012.

FERRUCCI JT, STARK DD: Iron oxide-enhanced MR imaging of the liver and spleen. Am J Roentgenol 155: 943-950, 1990.

GEETHA K, RAGHAVAN MSS, KULSHRESHTHA SK, SASIKALA R, RAO CP: Transition-metal saccharide chemistry: Synthesis, spectroscopy, electrochemistry and magnetic susceptibility studies of iron(III) complexes of mono- and disaccharides. Carbohydrate Res 271: 163-175, 1995.

GILDERSLEEVE JC, OYELARAN O, SIMPSON JT, ALLRED B: Improved procedure for direct coupling of carbohydrates to proteins via reductive amination. Bioconjug Chem 19: 1485-1490, 2008.

GRADY JK, CHASTEEN ND, HARRIS DC: Radicals from “Good's" buffers. Analyt Biochem 173: 111-115, 1988.

IFFAT AT, MAQSOOD ZT, FATIMA N: Study of complex formation of Fe (III) with tannic acid. J Pak Chem Soc 27: 174-177, 2005.

KAMAT M, EL-BOUBBOU K, ZHU DC, LANSDELL T, LU X, LI W, HUANG X: Hyaluronic acid immobilized magnetic nanoparticles for active targeting and imaging of macrophages. Bioconjug Chem 21: 2128-2135, 2010.

KEKKONEN V, LAFRENIERE N, EBARA M, SAITO A, SAWA Y, NARAIN R: Synthesis and characterization of biocompatible magnetic glyconanoparticles. J Magn Magn Mater 321: 1393-1396, 2009.

KRAEMER SM: Iron oxide dissolution and solubility in the presence of siderophores. Aquat Sci 66: 3-18, 2004.

LEMIEUX GA, BERTOZZI CR: Chemoselective ligation reactions with proteins, oligosaccharides and cells. Trends Biotech 16: 506-513, 1998.

LU Y, YIN Y, MAYERS BT, XIA Y: Modifying the surface properties of superparamagnetic iron oxide nanoparticles through a sol-gel approach. Nano Lett 2: 183-186, 2002.

MASEL R: Langmuir adsorption model. In: Principles of Adsorption and Reaction on Solid Surfaces. WileyInterscience, New York, 1996, pp 239-244.

MASSART R: Preparation of aqueous magnetic liquids in alkaline and acidic media. IEEE Trans Magn 17: 1247-1248, 1981.

OLDEN K, PARENT JB, WHITE SL: Carbohydrate moieties of glycoproteins; a re-evaluation of their function. Biochim Biophys Acta 650: 209-232, 1982.

PATSULA V, MOSKVIN M, DUTZ S, HORÁK D: Size-dependent magnetic properties of iron oxide nanoparticles. J Phys Chem Solids 88: 24-30, 2016.

PLUG CM, DECKER D, BULT A: Complex stability of ferrous ascorbate in aqueous solution and its significance for iron absorption. Pharm Weekblad 16: 245-248, 1984.

POLÁKOVÁ L, RAUS V, KOSTKA L, BRAUNOVÁ A, PILAŘ J, LOBAZ V, PÁNEK J, SEDLÁKOVA Z: Antioxidant properties of 2-hydroxyethyl methacrylate-based copolymers with incorporated sterically hindered amine. Biomacromolecules 16: 2726-2734, 2015.

ROQUE ACA, BICHO A, BATALHA IL, CARDOSO AS, HUSSAIN A: Biocompatible and bioactive gum Arabic coated iron oxide magnetic nanoparticles. J Biotech 144: 313-320, 2009.

SUN YK, MA M, ZHANG Y, GU N: Synthesis of nanometer-size maghemite particles from magnetite. Colloids Surf 245: 15-19, 2004. 
WANG YX: Superparamagnetic iron oxide based MRI contrast agents: Current status of clinical application. Quant Imaging Med Surg 1: 35-40, 2011.

WILHELM C, BILLOTEY C, ROGER J, PONS JN, BACRI JC, GAZEAU F: Intracellular uptake of anionic superparamagnetic nanoparticles as a function of their surface coating. Biomaterials 24: 1001-1011, 2003.

WINTERBOURN CC: Toxicity of iron and hydrogen peroxide: The Fenton reaction. Toxicol Lett 82: 969-974, 1995.

WUST P, GNEVECKOW U, JOHANNSEN M, BÖHMER D, HENKEL T, KAHMANN F, SEHOULI J, FELIX R, RICKE J, JORDAN A: Magnetic nanoparticles for interstitial thermotherapy - feasibility, tolerance and achieved temperatures. Int J Hyperthermia 22: 673-685, 2006. 